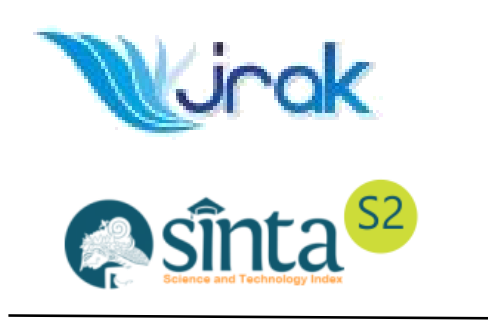

Website:

ejournal.umm.ac.id/index.php/jrak

*Correspondence:

ikearisanti@umm.ac.id

DOI: $\underline{10.22219 / \text { irak.v11i1.15560 }}$

Citation:

Jati, A.W., Naufal, M., Arisanti, I., \& Syam, D. (2021). Asset Specificity On Conditional Conservatism. Jurnal Reviu Akuntansi dan Keuangan, 11(1), 1-16.

Article Process

Submitted:

February 11, 2021

Reviewed:

April 19, 2021

Revised:

April 26, 2021

Accepted:

April 28, 2021

Published:

May 04, 2021

Office:

Department of Accounting University of

Muhammadiyah Malang

GKB 2 Floor 3.

Jalan Raya Tlogomas 246,

Malang, East Java,

Indonesia

P-ISSN: 2615-2223

E-ISSN: 2088-0685
Article Type: Research Paper

\section{ASSET SPECIFICITY ON CONDITIONAL CONSERVATISM}

\author{
Ahmad Waluya Jati ${ }^{1}$, Mohammad Naufal ${ }^{1}$, Ike Arisanti ${ }^{1 *}$ \\ Dhaniel Syam ${ }^{1}$ \\ Afiliation: \\ ${ }^{1}$ Faculty of Economics and Business, University of Muhammadiyah \\ Malang, East Java, Indonesia
}

\section{ABSTRACT}

Asset specificity, an asset creates company's distinctive competency that tough to be imitated by competitor. Howere asset specificity features a direct impact on a firm's in progress truthful price determination, bankruptcy risk, liquidation value, and abandonment option. On alternative hand, the ownerhip of this quality specificity has serious consequences on finance strategy. Bank faces serious issue to create a correct valuation of specific and opaque asset so bank charges higher value of debt. we discover no distinction within the extent to that good news is delayed in earnings for corporations conditional on asset specificity. This study use 280 non finance service and non agriculture type listed in IDX on 2018. However The information assortment used documentation technique and also the data analysis utilized was multiple correlation analysis. we have a tendency to document a significant negative association between quality specificity and conditional conservatism especially in Mining, Miscellaneous industry, and good consumer Industry But we notice new findings within the infrastructure sector there's a significant positive impact of specificity Asset specificity on conservatism.

KEYWORDS: Asset Specificity; Conditional Conservatism; Timeliness Loss Recognition 


\section{INTRODUCTION}

The global competition index in 2018 shows that Indonesia ranks 47 out of 195 total countries grouped (CNBC Indonesia). This description shows how much the ability of the business environment to support the sustainability of business competition, which is the benchmark for how much the country creates the conditions desired by the market. The higher score index get, it raises an assumption that the business environment is full of high and competitive business competition. The higher of the competition, can be affect the higher the strategic level pattern in facing business competition. In the strategic management concept, there are two views that state how the company's strategy is structured, first with a market-based strategy and the second with a resources-based strategy (Shou et al., 2013) The difference in the application of these strategies emergence from the principle that market-based strategy focuses on competition and changes in consumer behavior that are oriented towards anticipating and taking advantage of market opportunities. The difference in the application of these strategies appropriate from the principle that market-based strategy focuses on competition and changes in consumer behavior that are oriented towards anticipating and taking advantage of market opportunities. Thusfore in the resources-based strategy it states that the company should focus on developing the company's internal resources so that real competencies can be obtained which can result in the company being able to cope with changes in the external environment (Agha et al., 2011). An asset specificity in a company can make it a resourcesbased strategy which is the basis for creating a company's distinctive competence (De Vita et al., 2011). On the other hand assets spesifisitas more capabilities for the company by themselves must have characteristics that meet specific requirements so that it is difficult for competitors to imitate but requires a large amount of money to be able to maintain the specificity of these assets (Mingyue, 2011). The specificity contained in an asset must be in the form of special characteristics of the asset which can be called the opacity dimension, which must exist in an asset with a long time vulnerability so that its value for the company remains high (Mingyue, 2011). Real asset illiquidity likehood especially harmful in bad times, when firms are under pressure to restructure their operations and maneuver to avoid default. In particular, real asset illiquidity can induce firms facing economic adversity to remain burdened with unproductive assets, which often generate large fixed costs (OrtizMolina and Phillips, 2014)

According De Vita et al., (2011) that specific assets have special characteristics with a high degree of confidentiality regarding their characteristics, operating processes, and their relationship with unique internal company factors that become confidentiality must have the possibility of sustainability in the asset itself. Firms that already have specific assets have problems in financing, namely the high cost of implementing, strengthening and developing these can continue to create competitive advantage in the long term. The high cost of specific assets and the market price of specific assets that cannot be valued based on their fair value makes the recovery rate of these assets if the assets are liquidated very low (Benmelech, 2009). On the other hand, due to the lack of available resale value as a verified current asset value benchmark, companies with more specific assets tend to write down assets (Schonberger, 2015). Previous research has shown that the huge relationship between asset specificity and asymmetric information is due to their uniqueness (Aboody and Baruch, 2000). In addition, in order to reduce the value impact caused by information asymmetry between managers and shareholders, financial reporting requirements are becoming more and more conservative. Debt holders may require that the assets and income used in debt contracts and incentive-based compensation be carried out. A more 
conservative measure (LaFond and Watts, 2008). In this way, debt holders can prevent managers from paying excessive fees, while shareholders can leave company-specific assets to debt holders, which are far less than the face value of the debt at the time of liquidation (Holthausen and Watts, 2001). Shareholders may also require more conservative reporting to prevent managers from accepting overpayments and engaging in inefficient investments. The impact of the likelihood of the cost of assets The cost of capital will vary among companies in a manner roughly consistent with inflexible channels of operation. Specifically, the effect will be greater when inflexible operating costs due to insufficient asset liquidity may be higher.

Zhong and Li (2017) revealed that conservatism has long had a significant impact on financial coverage and accounting practices at the company and country levels. Sterling (1970) even mentioned conservatism because of the most effective valuation principle in accounting. Research shows that shareholders, auditors, regulators, suppliers, customers, and debt holders require accounting conservatism to reduce agency prices by reducing information asymmetry and promoting corporate governance. Together with corporate governance, conservatism can increase investment potential and reduce investment risks. Information about changes in the time series suggests that financial reporting is more conservative. In general, with the support of the previous analysis on conservatism, the conclusion is that conservatism is still one of the most important and necessary attributes of currency reporting it deserves additional analytical attention exclude. Shareholder-related performance evaluation uses financial reports for each evaluation, which is called effective capture. Conservative financial reporting is not suitable for valuation because it may provide investors with biased data, and conservatism is important for effective signing (Kothari et al., 2010). Although shareholder-related performance evaluation uses financial reporting for each valuation (Zhong and Li, 2017), they believe that managers play a special role in implementing conservatism. Accounting principles usually give managers discretion. For example, accounting standards provide managers with many depreciation methods. On the one hand, managers will use their own judgment to provide high-quality accounting statements to accurately replicate the company's economic conditions. On the contrary, managers can use their own judgment to report accounting figures in line with their own motivations and reduce the value of the company, which is called management opportunism. For conservative accounting principles, managers also have considerable discretion. The manager confirms the amount of future capital flows coming and the time of recording the assets. Watts, 2003) proposed four rationalizations for conservatism: contract interpretation, legal procedure interpretation, tax interpretation and restrictive interpretation. Look at it from another angle. Zhong and $\mathrm{Li},($ 2017) believe that conservatism is required in four main areas: debt holders, shareholders, auditors and regulators. As mentioned earlier, managers play a special role in accounting conservatism. Accounting standards usually adopt conservative principles, which are similar to the price or market accounting of inventories and the accounting of impairment of tangible and intangible assets (Kabir and Laswad, 2014). Accounting conservatism is a very important principle in the accounting process. Conservatism is an effective contract mechanism that can reduce agency and main asymmetric information generated by contract subjects (Ahmed et al., 2002).

JRAK

In contract theory Ahmed et al., (2002), conservatives have developed an effective contract 11.1 mechanism to reduce the system friction related to the contractor's information asymmetry and loss of function, as well as the inability to verify more private information. Conservative accounting requirements require the recognition of gains to be higher than 
the recognition of losses, and speed up the understanding of bad news/loss consequences, so as to ensure that external creditors and shareholders will not be too high and cause losses. The unrealized part of value can be divided into "good news" and "bad news", as long as "good news" means that the expected cash flow is positive, and "bad news" means that the expected cash flow is negative. Basu (1997) explained accounting conservatism to capture accountants' tendency that they want to obtain a better degree of verification than dangerous news in financial statements to identify excellent news. Therefore, as time goes by, "good news" is gradually identified, while "bad news" is incorporated into revenue in a very timely manner during the current period. Each "good news" and "bad news" is usually identified by accruals. A lot of accounting analysis relies on Basu (1997) the segmented statistical regression of positive and negative stock returns to find asymmetric and timely loss recognition or conditional conservativeness in the company's financial reports. In general, the research institute intuitively assumes that the progressive constant of negative returns collectively referred to as the non-timeliness (AT coefficient) can effectively measure the degree of conservativeness in accounting. Zhong and $\mathrm{Li}$ (2017) revealed that these definitions of Basu 1997 are useful. They did not take into account the specific economic environment and did not distinguish between different types of conservatism. As a result, measuring conservatism is difficult, so scholars have reached contradictory conclusions. (Basu, 1997) proposed an alternative definition of accounting conservatism, and proposed an easy-to-understand but easy-to-understand model. Each is defined and therefore the model is widely used. He explained conservatism as catching the trend of accountants, that is, compared with the bad news in the financial statements, accountants want better verification to identify good news. Under the principle of conservatism, income reflects much faster than bad news. This definition explains various changes in economic and financial gains and emphasizes the timeliness of identifying economic losses, that is, conditional conservatism.

Previous studies have shown $\mathrm{Li}$ and $\mathrm{Xu}$ (2018) that there is a relationship between specificity and conservatism, and the assumption of negative correlation also exists. It is also expected that when companies in highly competitive industries have institutional investors, can enter the public debt market and unsecured debt with explanations. As described in Kausar and Lennox (2017), assets with certain characteristics may lead to changes in conservative financial reporting practices, and the lack of conservatism in the balance sheet indicates that asset specificity may be related to lack of conservatism. Therefore, the decline in the competitiveness index of the companies listed on IDX in 2018 is due to the emergence of competitiveness or excessive conservatism of the companies.

Watts et al., (1978) reveals conservatisms because of the rule accountants should report the historical low of all viable asset values, so the substitute value of liabilities is the highest. In addition, revenue should be recognized late, and expenditure should be recognized late. This definition explains the scope of financial coverage and suggests that conservatism may be a characteristic of financial reporting. LaFond and Watts (2008) found that conservatism is attributable to the use of financial statements in debt and/or compensation contracts, litigation, regulatory and political procedures, and taxation. Information and loss functions between parties; and since it is impossible to verify the private information of parties with more information, the above argument implies that more conservative companies have different information between managers and external investees the symmetry is lower. Unconditional conservatism, also known as journalistic independence or ex-ante conservatism, means that the expected unrecorded goodwill is generated in all aspects of

JRAK 11.1 
the accounting methods that determine the sources of assets and liabilities. Examples of unconditional conservatism include immediately generating the value of internally generated intangible assets and amortizing durable assets at a rate higher than the expected economic amortization rate. Conditional conservatism, also called journalistic conservatism or hindsight conservatism, means that book value is recorded under sufficiently unfavorable circumstances, but it seems that it is not recorded under favorable circumstances. The sample of conditional conservatism includes the lower cost or market share of inventory and the percentage of impairment of persistent tangible and intangible assets (Zhong and Li, 2017). Each conservatism style will make the value of online assets attractive relative to their market prices (Kabirandwa 2014). LaFond and Watts (2008) Information asymmetry will change. The test relies on conservativeness to change information asymmetry. There is reason to believe that in many cases, conservatism will react quickly to changes in information asymmetry. In addition, the liquidation or abandonment value of many specific assets is low, and compared with specific enterprises, the value of company-specific assets in the liquidation or abandonment is undoubtedly much lower (Williamson, 1998).

On the contrary, due to at least three reasons, asset specificity may lead to less conservativeness in financial reporting. First of all, due to the less various uses or the greater uncertainty in the effective use of assets, the disposal value of many specific assets is low and often difficult to measure (Williamsom, 1988). Contracts can prohibit investment and financial policies for companies with more specific assets, thereby increasing the risk of bankruptcy (Vicente-Lorente, 2001). LaFond and Watts (2008) pointed out that conservatism can help debt holders assess the adequacy of assets to repay loans and alleviate agency problems, thereby reducing the credit risk associated with loans. $\mathrm{Li}$ and $\mathrm{Xu}$ (2018) described the low probability of conservatism when the future prospects are good. For example, a company may cause unnecessary detriment to the particularity or illiquidity of assets due to the difficulty of selling in the market, but the value of assets is much higher in operation. In this case, the cost of false communication is also high for companies with more assets.

Asset spesifisitas have special characteristics, particularly high confidentiality its characteristics, operational processes, and its relationship with internal factors that is incredibly special. Such confidentiality should be maintained so as for that to be competitive supported these qualitys will be sustainable. With a logical framework like this, specific asset funding tends to use internal funding (De Vita et al., 2011). Li and Xu (2018) reveals there is a tendency to show the direction of the company in determining the risk of bankruptcy, liquidation and rejection options because they argue that asset specificity is an asset that is difficult to transfer and not easily liquidated. They also argue that the existence of asset specificity can change the demand for conservartism due to the high demand for consideration from creditors and shareholders to consider the consequences of business sustainability. Facing high asset specificity will affect the application of accounting conservatism. Ortiz-Molina and Phillips (2014) show that aset spesifisitas is a resourcebased strategy from operating inflexibility, and that it has an impact to firm's cost of capital.

JRAK Firms with more asset spesifisitas have a higher cost of capital than firms with low asset spesifisitas and firms cost of capital is higher during periods of high asset spesifisitas. Asset 11.1 specificity is the unique characteristic of an asset that creates advantages compete for companies that own it (De Vita et al., 2011). Asset specificity is multi-aspect which means that the specificity of an asset is a combination of four sources causes an asset to be 
unique, namely specific physically, operating procedures, place and, supporting human resources. Company investment in specific and opaque resources will be negatively related to the company's debt ratio because the company has to bear a higher cost of debt (Vilasuso and Minkler, 2001). The uniqueness of assets making it even more risky in the eyes of the bank. Apart from that the loan capacity of its assets opaque is also limited due to low recovery rate (James and Kizilaslan, 2014).

Myres and Rajan (1998) It is assumed that the particularity of assets reduces the cost of management discretion. This means that managers can sell assets and transfer value from bondholders and stock investors. The particularity of assets makes this very expensive. On the other hand, asset specificity reduces the expected dilution value, thereby reducing the risk of expropriated assets. In other words, asset specificity can actually reduce agency costs between managers and principals. Compared with companies with more ordinary assets, managers/auditors of companies with very special assets are less likely to be aware of any changes in resale value because these assets lack an active market.

\section{$\boldsymbol{H}_{1}:$ Asset Spesifisitas assosiative negative on conservatism}

\section{METHOD}

This type of research is associative research, which is a type of research that aims to analyze the relationship between. The population in this research are all sector except agricullture listed on the Indonesia Stock Exchange (IDX) in 2018. The sampling technique in this research used purposive sampling technique. The criteria for determining the sample in this research are as follows:

1.Non-Financial Services Companies that have complete data required by researchers.

2.Companies that do not record losses

3.Companies with shares that were not suspended by IDX in 2018

4.Companies with complete information on Yahoo Finance

There are 2 variabel in this search, namely conservatism as dependet variabel and aset spesifisitas as independent variabel. Conditional conservatism is the asymmetry of information on the timeliness of income from the recognition of bad news versus good news (Basu, 1997). The formula used in this study is least squares regression:

$\mathrm{NI}_{\mathrm{i},}=\alpha_{0}+\alpha_{1} \mathrm{NEG}_{\mathrm{t}}+\beta_{0} \mathrm{RET}_{\mathrm{t}}+\beta_{1} \mathrm{RET}_{\mathrm{t}}{ }^{*} \mathrm{NEG}_{\mathrm{t}}$

Which one $\mathrm{NI}_{\mathrm{i}}$ is the same as earnings per share of the company divided by the market price per share of the company at the start of the period. RET is a stock return company annuals, measured compound 12 (twelve) returns monthly shares that expire three months after the end of the fiscal year t. NEG is dummy variable equal to 1 for bad news and 0 for good news, dummy variable in the form of the number 1 if the company has a negative total return for 8 months before the end of the period and 3 months after the end of the period if the number 0 is the opposite. In the main calculation of asset specificity developed by De Vita et al., (2011) and Shou et al., (2013) there are 3 measurement tools, namely the ratio of internal RandD expenses to total sales, secondly the ratio of salary costs to total costs. Company operations, and finally marketing costs against net sales. However, in the study Wibowo, (2017) only salary costs and total operational costs have a significant effect on asset specificity because the indication that Indonesian companies have only arrived at the stage of maintaining confidentiality of ownership and the process of accumulating specific internal assets by providing a high enough salary to employees so that

JRAK 11.1 
loyalty employees can be safeguarded and information leakage to competitors can be prevented.

Aset Spesifistas $=\frac{\text { Total Salery }}{\text { Total Cost }}$

However as Ball et al., (2013) obtain indicate the basu regression incrase coeffesient on negative returns, $\mathrm{RET}_{\mathrm{it}} \mathrm{x} \mathrm{NEG}_{\mathrm{it}}$ is a biased estimator of the relation between the news components of returns and earning when there is no control for cross sectional variation. In the end we include MB (Roychowdhury and Watts, 2007), SIZE (Givoly et al., 2007), DAR (Ahmed et al., 2002), and AGE (Khan and Watts., 2009). The Finall our regrestion after include variabel control is :

$\mathrm{Ni}=\beta_{0}+\beta_{1} \mathrm{NEG}+\beta_{2} \mathrm{ASPK}+\beta_{3} \mathrm{MB}+\beta_{4} \mathrm{SIZE}+\beta_{5} \mathrm{DAR}+\beta_{6} \mathrm{AGE}+\beta_{7} \mathrm{ASPK} * \mathrm{NEG}+$ $\beta_{8} \mathrm{MB}^{*} \mathrm{NEG}+\beta_{9}$ SIZE*NEG $+\beta_{10} \mathrm{DAR}^{*} \mathrm{NEG}_{-1}+\beta_{11} \mathrm{AGE}^{*} \mathrm{NEG}+\beta_{12} \mathrm{RET}+$ $\beta_{13} \mathrm{ASPK} * \mathrm{RET}+\beta_{14} \mathrm{MB} * \mathrm{RET}+\beta_{15} \mathrm{SIZE} * \mathrm{RET}+\beta_{16} \mathrm{DAR} * \mathrm{RET}+\beta_{17} \mathrm{AGE} * \mathrm{RET}+\beta_{18} \mathrm{NEG} *$ RET $+\beta_{19}$ASPK$^{*} \mathrm{NEG}^{*} \mathrm{RET}+\beta_{20} \mathrm{MB}^{*} \mathrm{NEG}^{*} \mathrm{RET}+\beta_{21} \mathrm{SIZE}^{*} \mathrm{NEG}^{*} \mathrm{RET}+\beta_{22} \mathrm{DAR} *$ NEG* RET $+\beta_{23} \mathrm{AGE}^{*} \mathrm{NEG}^{*} \mathrm{RET}$

DAR divided by the total debt by the company's total assets, MB divided by the market value by the book value of the company's equity, the AGE measurement of the logarithmic natural years at the end of the fiscal year expressed by AGE, and the SIZE twice accounting measured by Log the natural market value of the company at the end of the year.

\section{RESULTS AND DISCUSSION}

This research we divided the sampel into 7 sectors according to those determined by IDX as the legal authority as an institution of publicly traded companies. This classification aims to show comprehensive evidence and separation according to sectors in order to be able to broadly prove the phenomenon and explain in detail each sector. 7 sectors include: Mining, Basic Industry and Chemicals, Goods and Consumption Industry, Miscellaneous Industry, Consumer Goods Industry, Property, Infrastructure, Trade Services and Investment.

\begin{tabular}{lc}
\hline \multicolumn{1}{c}{ Sample Criteria } & Number \\
\hline Companies liested on IDX in 2018 & 627 \\
\hline Companies gain a loss in 2018 & $(186)$ \\
\hline Companies observation in the Agriculture in 2018 & $(13)$ \\
\hline Companies observation in the Finance in 2018 & $(91)$ \\
\hline Companies recently listed on IDX in 2018 & $(56)$ \\
\hline Companies have missing data for this research & $(21)$ \\
\hline Final Sample & 280 \\
\hline
\end{tabular}

Table 1.

Research Sample Criteria

\begin{tabular}{|c|c|c|c|c|c|c|c|}
\hline & Variabel & Minimum & Maximum & Average & Median & Standar Dev & \\
\hline & Neg & 0.000000 & 1.000000 & 0.525597 & 1.000000 & 0.500199 & \multirow{8}{*}{$\begin{array}{l}\text { Table } 2 . \\
\text { Descriptive } \\
\text { Statistic of } \\
\text { Variabel } \\
\text { Data } \\
\text { Hierarchy } \\
\text { Results }\end{array}$} \\
\hline & Ret & -0.881330 & 0.643835 & -0.007085 & -0.009567 & 0.243391 & \\
\hline & Aspk & 0.071758 & 0.788515 & 0.454312 & 0.456380 & 0.135326 & \\
\hline \multirow{5}{*}{$\begin{array}{r}\text { JRAK } \\
11.1\end{array}$} & $\mathbf{Y}$ & 0.005256 & 0.584838 & 0.225779 & 0.210407 & 0.113392 & \\
\hline & Age & 0.693147 & 3.583519 & 2.424389 & 2.708050 & 0.838590 & \\
\hline & Dar & 0.020000 & 4.700000 & 0,450341 & 0.440000 & 0.316722 & \\
\hline & Size & 23.05950 & 33.73021 & 28.52868 & 28.55829 & 1.831939 & \\
\hline & $\mathbf{M b}$ & -4.65000 & 71.59000 & 2.542696 & 1.170000 & 8.779230 & \\
\hline
\end{tabular}


Based on the results of table 2 the descriptive statistical test with E-Views 9, it shows that the highest value $(\max )$ for conservatism is 0.584838 while the lowest value ( $\mathrm{min}$ ) for conservatism is 0.005256 and the median value is 0.210407 and the standard deviation of these variables is 0.113392 . On the other hand the value of the standard deviation of conservatism is 0.113392 with the mean or average value of conservatism of 0.210407 , which means that the mean value is greater than the standard deviation, thus indicating a fairly good result. Because the standard deviation is a reflection of a very high deviation, the data distribution shows normal results and does not cause bias. The independent variable in this research is Asset Specificity which is based on the results of descriptive statistical tests with E-Views9 which shows that the highest value (max) of Asset Specificity is 0.788515 , while the lowest value ( $\mathrm{min}$ ) Asset Specificity is 0.071758 . On the other hand, the value of the standard deviation of Assets Specificity is 0.135326 with the mean or average value of Assets Specificity of 0.456380, which means that the mean value is greater than the standard deviation, thus indicating a fairly good result. Because the standard deviation is a reflection of a very high deviation, so that the data distribution shows normal results and does not cause bias.

Table 3 above reports the pairwise correlations between variables. The Spearman correlation coefficient is above (below) the diagonal. Correlation is usually consistent with previous analysis and has the expected signs. For example, $\mathrm{Ni}$ is positive for RET and NEG is negative. However, the size of most correlations is not large. We tend to consider collinearity medicine for all empirical models, and conclude that collinearity has no effect on our inferences.Classic

Table 3.

\begin{tabular}{lrrrrrrrr}
\hline & Ni & NEG & RET & ASPK & DAR & PBV & SIZE & AGE \\
\hline \multirow{2}{*}{ Ni } & 1,0000 & 0,1341 & 0,0914 & 0,0454 & 0,0148 & 0,1775 & 0,1592 & 0,0848 \\
& - & & - & & - & & - & - \\
NEG & 0,1341 & 1,0000 & 0,7529 & 0,1435 & 0,0459 & 0,0051 & 0,0876 & 0,0377 \\
& & - & & - & - & & & \\
RET & 0,0914 & 0,7529 & 1,0000 & 0,0774 & 0,0345 & 0,0536 & 0,0997 & 0,0207 \\
& & & - & & & - & - & - \\
ASPK & 0,0454 & 0,1435 & 0,0774 & 1,0000 & 0,1009 & 0,0900 & 0,1038 & 0,0458 \\
& - & - & - & & & & - & - \\
DAR & 0,0148 & 0,0459 & 0,0345 & 0,1009 & 1,0000 & 0,0514 & 0,0447 & 0,0430 \\
& - & & & - & & & & \\
PBV & 0,1775 & 0,0051 & 0,0536 & 0,0900 & 0,0514 & 1,0000 & 0,3208 & 0,0146 \\
& - & - & & - & - & & & \\
SIZE & 0,1592 & 0,0876 & 0,0997 & 0,1038 & 0,0447 & 0,3208 & 1,0000 & 0,0089 \\
& & - & & - & - & & & \\
AGE & 0,0848 & 0,0377 & 0,0207 & 0,0458 & 0,0430 & 0,0146 & 0,0089 & 1,0000 \\
\hline
\end{tabular}

\section{Asusumption Test}

One of the method that can be used is to use the Jarque-Bera, this method shows that is a goodness of fit test which measures whether the skewness and kurtosis of the sample are in accordance with the normal distribution. From the table 3 above, it can be seen that the Jarque Berra probability value must more than 0,05 it means that the research data residuals are normally distributed. 
9

\begin{tabular}{lcc}
\hline Sector & Jarque-Bera & Normality \\
\hline Meaning & $\mathbf{2 . 4 8 5 1 4 1}$ & $\mathbf{0 . 2 8 8 6 4 1}$ \\
Basic Industry and Chemical & $\mathbf{0 . 0 9 6 0 6 6}$ & $\mathbf{0 . 9 5 3 1 0 2}$ \\
Miscellaneous Industry & 0.052851 & 0.973921 \\
Consumer Good Industry & $\mathbf{3 . 0 5 4 0 8 7}$ & $\mathbf{0 . 2 1 7 1 7 7}$ \\
Property, Real Estate, Building Construction & $\mathbf{1 . 6 7 5 4 9 1}$ & $\mathbf{0 . 4 3 2 6 8 5}$ \\
Infrastructure, Utility, and Transportation & $\mathbf{0 . 5 3 1 3 3 2}$ & $\mathbf{0 . 7 6 6 6 9 5}$ \\
Trade, Service, and Investment & $\mathbf{2 . 4 3 3 4 7 1}$ & $\mathbf{0 . 2 9 6 1 9 6}$ \\
\hline
\end{tabular}

Table 4.

Normality

Test

\section{Heteroskedasticity Test}

\begin{tabular}{lc}
\hline \multicolumn{1}{c}{ Sector } & $\begin{array}{c}\text { Heteroskedasticity Test: Breusch-Pagan- } \\
\text { Godfrey }\end{array}$ \\
\hline Meaning & 0.8657 \\
Basic Industry and Chemical & 0.4375 \\
Miscellaneous Industry & 0.8057 \\
Consumer Good Industry $\quad$ Building & 0.7898 \\
Property, Real Estate, & 0.1302 \\
Construction & \\
Infrastructure, Utility, and Transportation & 0.9532 \\
Trade, Service, and Investment & 0.1956 \\
\hline
\end{tabular}

Table 5.

Heteroskedas ticity Test

Data Processed

If all the classical assumptions are valid, except for one which is not, that is, they occur heteroscedasticity, then the Ordinary Least Squares estimator is still unbiased and consistent however it is no longer efficient both for small samples and for large samples. With P-Value over 0.05 then it can be said that the regression model is homoscedasticity or in other words there is no problem with the assumption of non-heteroscedasticity

\section{Hypothesis Test}

Effect Asset Spesifisitas on Conservatism

This section we divide the table 3 category, first Aset spesifisitas assosiative significant negative on conservatism, second Aset spesifisitas has't assosiative significant on conservatism, and the last our new finding Aset spesifisitas significant positive on conservatism at the same time refusing our $\mathrm{H}_{1}$.

Coefficient $\beta_{12}$ estimates the relationship between RET measured at the time of accuracy of earnings and good news. $\beta_{18}$ (Coeffesient for RET*NEG) measures the asymmetry of the timeliness of the return on bad news which projects if it produces a positive sign then it shows that the company undertake conservatism. $\beta_{13}$ and $\beta_{19}$ are representative of the timeliness measurement in earning recognition of good news (ASPK*RET) and bad news (ASPK*RET*NEG) on the conservatism of asset specificity, produces estimate which has a broad meaning of the impact of the economy.

\section{JRAK}

\section{1}


Aset Spesifisitas assosiative negative significant on conservatism

\begin{tabular}{|c|c|c|c|c|c|c|}
\hline \multirow[b]{2}{*}{ Variabel } & \multicolumn{2}{|c|}{ Mining } & \multicolumn{2}{|c|}{$\begin{array}{l}\text { Miscellaneous } \\
\text { Industry }\end{array}$} & \multicolumn{2}{|c|}{$\begin{array}{l}\text { Consumer Good } \\
\text { Industry }\end{array}$} \\
\hline & $\begin{array}{c}\text { Coefficie } \\
\text { nt }\end{array}$ & Prob & $\begin{array}{c}\text { Coefficie } \\
\text { nt }\end{array}$ & Prob & $\begin{array}{c}\text { Coefficie } \\
\text { nt }\end{array}$ & Prob \\
\hline INTERCEPT & 2.034440 & 0.0296 & 0.163879 & 0.7502 & 0.497239 & 0.0805 \\
\hline NEG & $\begin{array}{c}- \\
0.951090\end{array}$ & 0.4646 & 1.208849 & 0.1386 & $\begin{array}{c}- \\
0.466681\end{array}$ & 0.2420 \\
\hline RET & $\begin{array}{c}- \\
7.964152\end{array}$ & 0.0612 & -1.226199 & 0.6129 & 2.801883 & $\begin{array}{c}0.0537 * \\
*\end{array}$ \\
\hline ASPK & 0.318472 & 0.2766 & $\begin{array}{c}- \\
0.386166\end{array}$ & $0.0941 *$ & $\begin{array}{c}- \\
0.725860\end{array}$ & $0.0711 *$ \\
\hline RET*NEG & 7.237269 & 0.1692 & 7.149105 & 0.1438 & 2.587014 & 0.1513 \\
\hline ASPK*RET & 1.354087 & 0.2432 & 1.834265 & 0.1602 & 5.152085 & $\begin{array}{l}0.0189 * \\
*\end{array}$ \\
\hline ASPK*NEG & $\begin{array}{c}- \\
0.996395\end{array}$ & $\begin{array}{c}0.52610 \\
5\end{array}$ & -0.101052 & 0.7849 & 0.812867 & 0.1740 \\
\hline ASPK*NEG*RET & $\begin{array}{c}- \\
3.303176\end{array}$ & $\begin{array}{c}0.0406^{*} \\
*\end{array}$ & $\frac{-}{6.176003}$ & $\begin{array}{c}0.0332 * \\
*\end{array}$ & $\begin{array}{c}- \\
5.152563\end{array}$ & $0.0720 *$ \\
\hline CONTROL & YES & YES & YES & YES & YES & YES \\
\hline CONTROL*RET & YES & YES & YES & YES & YES & YES \\
\hline CONTROL*NEG & YES & YES & YES & YES & YES & YES \\
\hline $\begin{array}{l}\text { CONTROL*NEG*R } \\
\text { ET }\end{array}$ & YES & YES & YES & YES & YES & YES \\
\hline Sampel & 31 & 31 & 28 & 28 & 33 & 33 \\
\hline Adj R-Squared & & $\begin{array}{c}0.68299 \\
0\end{array}$ & & $\begin{array}{c}0.16036 \\
0\end{array}$ & & $\begin{array}{c}0.30114 \\
1\end{array}$ \\
\hline F-statistic & & $\begin{array}{c}3.81018 \\
0\end{array}$ & & $\begin{array}{c}2.25786 \\
5\end{array}$ & & $\begin{array}{c}2.55825 \\
6\end{array}$ \\
\hline Prob (F-statistic) & & $\begin{array}{c}0.03758 \\
9\end{array}$ & & $\begin{array}{c}0.03832 \\
1\end{array}$ & & $\begin{array}{c}0.04263 \\
7\end{array}$ \\
\hline $\begin{array}{l}\text { Data Processed } \\
* \quad=\text { Significant in } 10 \% \\
* *=\text { Significant in } 5 \% \\
* * *=\text { Significant in } 1 \%\end{array}$ & & & & & & \\
\hline
\end{tabular}


11

Aset Spesifisitas assosiative positive significant on conservatism

\begin{tabular}{clcc}
\hline \multicolumn{1}{c}{ Sector } & \multicolumn{1}{c}{ Variabel } & Coefficient & Prob \\
& INTERCEPT & $\mathbf{0 . 2 1 3 6 9 9}$ & $\mathbf{0 . 7 5 0 8}$ \\
& NEG & $\mathbf{3 . 2 7 9 3 7 7}$ & $\mathbf{0 . 0 2 6 3} * \boldsymbol{0 . 1 1 6 3}$ \\
& RET & $\mathbf{1 1 . 0 7 3 8 0}$ & $\mathbf{0 . 1 6 3}$ \\
& ASPK & $\mathbf{- 0 . 2 9 1 0 9 3}$ & $\mathbf{0 . 4 1 9 9}$ \\
& RET*NEG & $\mathbf{1 3 . 6 6 5 4 4}$ & $\mathbf{0 . 2 0 1 1}$ \\
Infrastructure & ASPK*RET & $\mathbf{2 . 3 7 3 1 5 1}$ & $\mathbf{0 . 3 7 4 8}$ \\
& ASPK*NEG & $\mathbf{3 . 7 2 7 5 1 2}$ & $\mathbf{0 . 0 0 5 2 * * *}$ \\
& ASPK*NEG*RET & $\mathbf{1 6 . 5 4 8 1 0}$ & $\mathbf{0 . 0 1 3 8 * *}$ \\
& CONTROL & YES & YES \\
& CONTROL*RET & YES & YES \\
& CONTROL*NEG & YES & YES \\
Sampel & CONTROL*NEG*RET & YES & YES \\
Adj R-Squared & & $\mathbf{3 2}$ & $\mathbf{3 2}$ \\
F-statistic & & & 0.571930 \\
Prob (F-statistic) & & & 2.800785 \\
\hline Data Processed & & & 0.037468 \\
\hline
\end{tabular}

Table 7.

Results of

Coeffesient

Determination $\mathrm{B}$

Data Processed

* = Significant in $10 \%$

$* *=$ Significant in $\mathbf{5 \%}$

$* * *=$ Significant in $1 \%$

Aset spesifisitas is not assosiative on conservatism

\begin{tabular}{|c|c|c|c|c|c|c|c|}
\hline \multirow[b]{2}{*}{ Variabel } & \multicolumn{2}{|c|}{$\begin{array}{l}\text { Basic Industry and } \\
\text { Chemicals }\end{array}$} & \multicolumn{2}{|c|}{$\begin{array}{c}\text { Trade Services and } \\
\text { Investment }\end{array}$} & \multicolumn{2}{|c|}{ Property } & \\
\hline & Coefficient & Prob & Coefficient & Prob & Coefficient & Prob & \\
\hline INTERCEPT & 1.279933 & 0.1002 & 1.543795 & 0.0366 & 0.000372 & 0.9998 & \\
\hline NEG & -0.630353 & 0.5225 & -1.838136 & $0.1038 *$ & 0.520117 & 0.7001 & \\
\hline RET & 0.343587 & 0.8587 & -3.733984 & 0.2370 & 3.775195 & 0.5028 & \\
\hline ASPK & 0.112168 & 0.6868 & -0.094681 & 0.7338 & -0.760329 & 0.5450 & \\
\hline RET*NEG & 8.4140414 & 0.2588 & 2.185850 & 0.6731 & -3.875789 & 0.5116 & \\
\hline ASPK*RET & 0.494155 & 0.5880 & 0.997320 & 0.4814 & 3.538003 & 0.3645 & \\
\hline ASPK*NEG & -0.379035 & 0.4399 & 0.054333 & 0.8907 & 0.778313 & 0.5456 & \\
\hline ASPK*NEG*RET & -1.613201 & 0.5138 & -0.979259 & 0.6440 & -4.653120 & 0.2579 & \\
\hline CONTROL & YES & YES & YES & YES & YES & YES & \\
\hline CONTROL*RET & YES & YES & YES & YES & YES & YES & \\
\hline CONTROL $*$ NEG & YES & YES & YES & YES & YES & YES & \\
\hline CONTROL $*$ NEG*RET & YES & YES & YES & YES & YES & YES & \\
\hline Sampel & 45 & 45 & 59 & 59 & 50 & 50 & Table 7. \\
\hline Adj R-Squared & & 0.283171 & & 0.083171 & & 0.123768 & $\begin{array}{l}\text { Results of } \\
\text { Coeffesient }\end{array}$ \\
\hline AKratistic & & 2.158765 & & 1.346907 & & 1.300925 & Determinat \\
\hline Prdb (F-statistic) & & 0.036786 & & 0.217691 & & 0.25083 & \\
\hline
\end{tabular}




\section{Data Processed \\ $* \quad=$ Significant in $10 \%$ \\ $* *=$ Significant in $5 \%$ \\ $* * *=$ Significant in $1 \%$}

This section we explain with two part, according aset spesifisitas assosiative negative significant on conservatism from tabel 6 consist of 3 sector among them Mining, Miscellaneous Industry, and Consumer Good Industry. Dividing companies listed on the Indonesia Stock Exchange aims to see as a whole every aspect of the sector arising from the affect of Asset Specificity on conservatism as a whole in appropriate with the company's long-term policy in facing threats and profits in the future. By doing the divide between each sector can provide a conclusion that produces differences according to each sector studied. The results of this test are proved in each table above form 4 have significant negative association between asset spesifisitas on conservatism which one same as prior reaserch $(\mathrm{Li}$ and $\mathrm{Xu}, 2018) . \beta_{13}$ are representative of the timeliness measurement in earning recognition of good news (ASPK*RET) exist in Consumer Good Industry with pvalue 0.0189 is significant positive $(0.0189<0.05)$ prior reaserch (LaFond and Watts, 2008), less conservatism can be supported by reducing the delay in loss identification and/or speeding up gain identification. This means that the good news represented by $\beta_{13}$ reflected in the income is affected by the special degree of assets. These result only apply to Consumer Good Industry having effect on how gains recognition is timeliness for good news and decreasing the timeliness with loss recognition for bad news. However focus on our primary estimation in $\beta_{19}$ (ASPK*RET*NEG) representative, conditional on conservatism. Our estimasi regresion result for $\beta_{19}$ (ASPK*RET*NEG) is significantly negative for Mining, Miscellaneous Industry, and Consumer Good Industry with their each p-value $(0.0406<0.05),(0.0332<0.05)$, and $(0.0720<0.1)$. These results also support previous research $(\mathrm{Li}$ and $\mathrm{Xu}, 2018)$ reveal that it is consistent with their expectations, where the coeffisient $\beta 19$ estimates that the (ASPK*RET*NEG) relationship is statistically negative only for industries that have low competitors. The coeffisient estimate of the (ASPK*RET*NEG) relationship is not significant if the industry has high competition. In other words, the inverse relationship between asset specificity and conditional conservatism is driven primarily by firms operating in more concentrated industries. In summary, the results in tables 6 prove that when asset specificity increases, bad news will have less impact on timely recognition of company earnings or otherwise. $\mathrm{Li}$ and $\mathrm{Xu}$ (2018) provide a detailed explanation of one of the reasons for the negative relationship between conservatism and asset specificity is the possibility of incorrect communication of low signals of a likely good future. With the active industry competence, shareholders and creditors can easily find comparisons between companies by using their accounting calculations as a measuring tools which one can reduce the error of signal caused by the application of conservatism but in low industry competence shareholders and debt holders do not have sufficiently sophisticated tools to consider how to view the business environment because market concentration is not tight and there are only a few main companies that are not quite evenly distributed. In other words, the inverse relationship between asset specificity and conditional conservatism is driven primarily by firms operating in more concentrated industries. LaFond and Watts (2008) argues that a lack of conservatism leads to a slowdown in loss recognition and an accelerated recognition of income or otherwise.

Myres and Rajan (1998) It is assumed that the particularity of assets reduces the cost of management discretion. In other words, managers can sell assets and transfer value from
JRAK

11.1 
bondholders and stock investors. The particularity of assets makes them very expensive.

13 Therefore, asset specificity reduces the expected dilution value, thereby reducing the risk of expropriated assets. In addition, when the market value cannot be obtained, the management's continuous analysis and review of its operations is likely to form the basis for determining impairment. Asset specificity may have a negative impact on the demand for accounting conservatism, thereby affecting the possibility and timeliness of asset impairment. When an asset's expected (undiscounted) future net cash flow value is less than the asset's book value, impairment occurs. Ortiz-Molina and Phillips (2014). Exposing asset fraud will increase the cost of capital for companies facing more competitive industries and closer to default, and for companies facing negative demand shocks, this situation will bring harmful and sufficient liquidity risks. Therefore, when the cost of false signals associated with conservative conservatism is high, creditors can demand less conservatism, and when agency costs are high, creditors can demand more conservatism.

The difference in the results in the Infrastructure sector that rejects $\mathrm{H}_{1}$ with a value of estimasi regresion result for $\beta_{19}$ (ASPK*RET*NEG) 0.0138 ( $\mathrm{p}$-val $<5 \%$ ). This difference indicates that the increase in asset specificity increases the conservatism of each company in the sector. There are several indications that give rise to this condition, companies in the Infrastructure sector are likely to convey the right signals of the future with what may be good or bad. With the active competence of the industry managers, shareholders, and creditors can easily find comparisons between companies by using their accounting calculations as a measure which can reduce the error signal caused by the application of conservatism. These differences lead to a new conclusion about the uniqueness of each sector due to market differences and policies that lead to long-term companies in facing challenges in the future. Table 5 provides different knowledge of these findings indicating the results of empirical tests are different from previous studies $\mathrm{Li}$ and $\mathrm{Xu}$, (2018) which suggest a significant negative effect between asset specificity and conditional conservatism.

Wibowo (2017) reveals that Indonesian companies have only reached the stage of maintaining confidentiality of ownership and a specific internal asset accumulation process by providing high enough salaries to employees so that employee loyalty can be maintained and information leakage to competitors can be prevented indicating that the infrastructure sector. On the other hand environment Indonesian businesses which one relatively rarely do research and development cause prefer to import from outside. Although previous research has shown that companies with specific assets are associated with large-scale information asymmetry due to their relative uniqueness. Kothari et al. (2010) can effectively alleviate the decrease in value caused by the information asymmetry between managers and external equity investors, and the increase in demand for conservatism. Likelihood value of asset spesificity in Infrastructure sector contains of different function and benefits with the argument that asset spesificity in Infrastructure sector be benchmark can also decrease false signal false signal for the future favorable This result rejects previous research $\mathrm{Li}$ and $\mathrm{Xu}$, (2018) and can be used as findings that can be used for further research, we expect existence information asymmerty related with required returns. Easley and O'Hara (2004) suggest on Their theory and experience prove that the data space is actively involved in balanced needs for returns. Managers tend to maximize their own interests by manipulating financial news and investing in inefficient projects. The deadweight loss due to the particularity of assets is the information asymmetry between managers, debt holders, and shareholders.

However, different things are shown in the Basic Industry and Chemical, Trade Services and Investment and Property sectors which do not show any influence between asset 
specificity and conservatism. For each, the p-val values are $0.5138,0.6440$, and 0.2579 . The absence of a significant effect between asset specificity and conservatism creates a broad economic meaning. This results indicates that there is no specific asset that each sector has which results in demand for conservatism. $\mathrm{Li}$ and $\mathrm{Xu}$ (2018) Their theory and experience prove that data space actively participates in the equilibrium demand for revenue. Managers tend to maximize their own interests by manipulating financial news and investing in inefficient projects. The deadweight loss caused by the particularity of assets is the information asymmetry among managers, debt holders and shareholders. This result also shows that the characteristics of a country cannot be compared with other countries.

\section{CONCLUSION}

This study aims to provide empirical evidence of the effect of the Specific anti avoidance rules (SAAR) represented by transfer pricing and thin capitalization on tax avoidance. Based on statistical tests conducted, it was found that transfer pricing and thin capitalization had no effect on tax avoidance.

The absence of influence of transfer pricing variables on tax avoidance is because the average multinational companies that were sampled carried out relatively small transfer pricing actions. Based on the results of this study it can be said that the transfer pricing scheme is not a scheme used by sample companies in carrying out tax avoidance practices.

Furthermore, thin capitalization variable has no effect on tax avoidance because based on sample company data, the average company does not use debt as a source of funding. The average source of funding for the sample companies is $75 \%$ comes from equity. As it is known that the source of funding from equity cannot be used as a loophole to avoid taxes.

The limitations of this study only use transfer pricing and thin capitalization as indicators of SAAR. For further research, it is better to use the five SAAR indicators, namely transfer pricing, thin capitalization, controlled foreign corporations (CFCs), the use of tax heaven countries, and treaty shopping. The implication in this research is that the government should consider implementing the General Anti Avoidance Rule (GAAR) to cover the weaknesses of SAAR. This is based on the results of research that proves that transfer pricing and thin capitalization have no effect on tax avoidance.

This study has limitations that will provide opportunities for further research to develop as well as deepen the factors that influence asset specificity on conservatism. The limitation of this study is that the data collection period in this study is only 1 year, namely 2018. In addition, there are possibilities that can still answer the phenomenon in this study more deeply if the observation is associated with other variables.

\section{REFERENCES}

Aboody, D., and Baruch, L. (2000). Information asymmetry, RandD, and insider gains. Journal of Finance, 55(6), 2747-2766. https://doi.org/10.1111/0022-1082.00305

Agha, S., Alrubaiee, L., and Jamhour, M. (2011). Effect of Core Competence on Competitive Advantage and Organizational Performance. International Journal of Business and Management, 7(1). https://doi.org/10.5539/ijbm.v7n1p192

Ahmed, A. S., Stanford-harris, M., Billings, B. K., and Norton, M. R. (2002). The Role of Accounting Conservatism in Mitigating Bondholdrs-Shareholders Conflict over Deviden Policy and In Reducing Debt Cost. The Accounting Review, 77(4), 876-890. https://doi.org/10.2308/accr.2002.77.4.867 
Basu, S. (1997). The conservatism principle and the asymmetric timeliness of earnings. Journal of Accounting and Economics, 24, 3-37. https://doi.org/10.1016/S01654101(97)00014-1

Benmelech, E. (2009). Asset salability and debt maturity: Evidence from nineteenth-century American railroads. In Review of Financial Studies (Vol. 22, Issue 4).

De Vita, G., Tekaya, A., and Wang, C. L. (2011). The many faces of asset specificity: A critical review of key theoretical perspectives. International Journal of Management Reviews, 13(4), 329-348. https://doi.org/10.1111/j.1468-2370.2010.00294.x

Easley, D., and O'Hara, M. (2004). Information and the cost of capital. Journal of Finance, 59(4), 1553-1583. https://doi.org/10.1111/j.1540-6261.2004.00672.x

Holthausen, R. W., and Watts, R. L. (2001). The relevance of the value-relevance literature for financial accounting standard setting. Journal of Accounting and Economics, 31(1-3), 375. https://doi.org/10.1016/S0165-4101(01)00029-5

James, C., and Kizilaslan, A. (2014). Asset specificity, industry-driven recovery risk, and loan pricing. Journal of Financial and Quantitative Analysis, 49(3), 599-631. https://doi.org/10.1017/S0022109014000143

Kabir, M. H., and Laswad, F. (2014). The behaviour of earnings, accruals and impairment losses of failed New Zealand finance companies. Australian Accounting Review, 24(3), 262-275. https://doi.org/10.1111/auar.12028

Kausar, A., and Lennox, C. (2017). Balance sheet conservatism and audit reporting conservatism. Journal of Business Finance and Accounting, 44(7-8), 897-924.

Kothari, S. P., Ramanna, K., and Skinner, D. J. (2010). Implications for GAAP from an analysis of positive research in accounting. Journal of Accounting and Economics, 50(2-3), 246-286. https://doi.org/10.1016/j.jacceco.2010.09.003

LaFond, R., and Watts, R. L. (2008). The Information Role Of Conservatism. The Accounting Review, 83(2), 447-478. https://doi.org/10.2308/accr.2008.83.2.447

Li, Q., and Xu, L. (2018). Asset specificity and conditional accounting conservatism. Journal of Business Finance and Accounting, 45(7-8), 839-870. https://doi.org/10.1111/jbfa.12308

Myres, C. S., and Rajan, R. (1998). The paradox of liquidity. Oxfordjournals, 113(3), 733-771. https://doi.org/10.1162/003355398555739

Ortiz-Molina, H., and Phillips, G. M. (2014). Real asset illiquidity and the cost of capital. Journal of Financial and Quantitative Analysis, 49(1), 1-32.

Roychowdhury, S., and Watts, R. L. (2007). Asymmetric timeliness of earnings, market-tobook and conservatism in financial reporting. Journal of Accounting and Economics, 44(12), 2-31. https://doi.org/10.1016/j.jacceco.2006.12.003

Schonberger, B. (2015). Real Asset Liquidity and Asset Impairments. SSRN Electronic Journal. https://doi.org/10.2139/ssrn.2597138

JRAK Shou, Z., Yang, L., Zhang, Q., and Su, C. (2013). Market munificence and inter-firm 11.1 information sharing: The moderating effect of specific assets. Journal of Business Research, 66(10), 2130-2138. https://doi.org/10.1016/j.jbusres.2013.02.039

Sias, R.W., Starks, L.T. and Titman, S., 2006. Changes in institutional ownership and stock 
returns: Assessment and methodology. The Journal of Business, 79(6), pp.2869-2910.

Sunder, J., Sunder, S.V. and Zhang, J., 2018. Balance sheet conservatism and debt contracting. Contemporary Accounting Research, 35(1), pp.494-524.

Vicente-Lorente, J. D. (2001). Specificity and Opacity As Resource-Based Determinants of Capital Structure : Strategic Management Journal, 177(June 1998), 157-177.

Vilasuso, J., and Minkler, A. (2001). Agency costs, asset specificity, and the capital structure of the firm. Journal of Economic Behavior and Organization, 44(1), 55-69. https://doi.org/10.1016/S0167-2681(00)00151-7

Watts, R. L. (2003). Conservatism in Accounting Part I: Explanations and Implications. Accounting Horizons: September 2003, 17(3), 207-221.

Watts, R. L., Zimmerman, J. L., and Ross Watts, S. L. (1978). Towards a Positive Theory of the Determination of Accounting Standards Towards a Positive Theory of the Determination of Accounting. Source: The Accounting Review THE ACCOUNTING REVIEW, 53(I), 112-134.

Wibowo, B. (2017). Kepemilikan aset spesifik, keunggulan kompetitif, dan struktur modal perusahaan: Studi kasus perusahaan publik di Indonesia. Jurnal Siasat Bisnis, 20(2), 115-129. https://doi.org/10.20885/jsb.vol20.iss2.art2

Zhong, Y., and Li, W. (2017). Accounting Conservatism: A Literature Review. Australian Accounting Review, 27(2), 195-213. https://doi.org/10.1111/auar.12107 